\title{
The Israeli Lobby and the U.S. Response to the War in Lebanon
}

On 28 August 2006, the Council on American-Islamic Relations (CAIR) sponsored a panel discussion on "The Israeli Lobby and the U.S. Response to the War in Lebanon" at the National Press Club, Washington, DC. Stephen Walt (Kennedy School of Government, Harvard) and John Mearsheimer (University of Chicago), authors of the controversial article "The Israeli Lobby and U.S. Foreign Policy," were featured.

The panel began with opening remarks by Corey Saylor (government affairs director, CAIR) and Nihad Awad (executive director, CAIR). Awad discussed the war in Lebanon and the situation in Gaza, described Israel's dropping of cluster bombs on civilian Lebanese towns, quoted a Human Rights Watch report that states Israel does not distinguish between combat- 
ants and civilians, as well as an Amnesty International report describing Israeli actions in Lebanon as war crimes. He concluded: "Our one-sided support for Israel is a liability in the war on terror. It has turned much of the world, including our European allies, against us."

Stephen Walt summarized the main arguments of his research article with John Mearsheimer. Among them are that comprehending the recent war in Lebanon requires an understanding of the pro-Israel groups' political power in the United States; that the Israeli lobby's influence has led to policies that are not in the United States' national interest, or in those of the region's countries, including Israel; and that $\$ 3$ billion of American taxpayers' money is given unconditionally to a wealthy industrial nation. $\mathrm{He}$ quoted former American negotiator Aaron Miller's remark that the United States acted as Israeli's lawyer during Oslo and has been even more onesided under President Bush.

Walt pointed out that while Israel may have been a strategic ally during the cold war, this is no longer the case: "We don't back Israel because we have a common threat from terrorism; rather, we have a common threat from terrorism because we have been so closely tied to Israel." He asserted that Israel is the main bone of contention with other Middle Eastern nations, that President Bush opposes Iran's nuclear ambition because it threatens Israel, and that the United States' unconditional support for Israel makes winning the war on terror harder. According to him, the perception of Israel as the "only democracy" in the Middle East and a nation surrounded by enemies is incorrect, for it has nuclear weapons and is the region's superpower. In fact, the main security issue is Israel's failure to achieve a just peace with the Palestinians. However, he does feel that there is a moral case for Israel to exist, based on the long history of anti-Semitism and the Holocaust, and that Israel has the right to defend itself.

After discussing Israel's treatment of Palestinians and the American Israel Public Affairs Committee's (AIPAC) influence in Washington, he analyzed what the world would be like if the lobby was less influential. For example, he stated that limiting and even abandoning settlements in the Occupied Territories would have prevented Palestinian reprisals and radicalization, saved billions of dollars, and improved Israel's world image. Walt also asserted that the United States has failed to support Mahmoud Abbas, who was democratically elected, recognizes Israel, rejects terror, and wants to negotiate. Instead, its endorsement of expanding existing settlements and building new ones enabled Hamas to win the recent elections.

After discussing the invasion of Iraq, which "was conceived by neoconservatives, many of them connected in the lobby, encouraged by many Israeli 
leaders, and endorsed openly by groups like AIPAC," he stressed that the Israeli lobby was not the only reason for invading Iraq: 9/11 was the key additional factor. Walt added that such neoconservatives as Paul Wolfowitz linked Saddam Hussein to 9/11 despite the lack of any connection. Without the lobby, the invasion would have been less likely and better American-Iranian relations, which the lobby also opposes, would have been more possible. He closed by defending his co-authored article against charges of anti-Semitism, factual errors, "sloppy" scholarship, and personal character attacks as well as mentioning that many other scholars reviewed the paper before publication. For example, L. Carl Brown (Princeton University) refuted the anti-Semitic and "sloppy" claims and referred to the paper as "a hard headed analysis that just might set in motion a useful paradigm shift in US-Middle East policy."

John Mearsheimer began by describing the United States' extensive support of Israel during the recent war in Lebanon, which, he stated, made no strategic or moral sense. The main reason for American support was the lobby. Mearsheimer examined reasons for that support, American public opinion and foreign policy, and the notion of Israel as an American client state during the Lebanon conflict. In short, he argued that the administration's Lebanon policy was not in the United States' or Israel's national interest.

The Bush administration's support began with an enthusiastic endorsement to allow Israel to destroy Hezbollah. Mearsheimer added that Israel clearly had intended to confront Hezbollah long before the kidnappings. Despite severe international criticism, the Bush administration vetoed United Nations' resolutions, prevented a cease-fire to allow Israel to infiltrate Hezbollah, and provided smart bombs. Ehud Olmert thanked Bush for "safeguarding Israel's interest in the Security Council."

Congress also voted unanimously to support Israel, and the mainstream American media backed Israel and did not condemn its attacks against civilians and Lebanon's infrastructure. This was remarkable, added Mearsheimer, as almost every other nation plus the United Nations criticized Israel. However, this war undermined the United States' position in the Middle East as regards terrorism, rogue states (viz., Iran and Syria), and the war in Iraq. Furthermore, American policy in the region has alienated such friendly regimes as Egypt and Jordan and angers our European allies.

Mearsheimer asserted that the war had two components: to destroy Hezbollah and to punish Lebanon and its people. When Hezbollah killed three Israeli soldiers and captured two more near the Israel-Lebanon border on 12 July 2006, Israel responded by bombing Lebanon and Hezbollah responded by firing rockets into northern Israel. The result: 1,183 Lebanese (one-third of them children) were killed, 750,000 refugees were created, and 
catastrophic damage was done to Lebanon's infrastructure. Human Rights Watch concluded: "Israel has violated one of the most fundamental tenets of the laws of war, the duty to carry out attacks on only military targets" and declared that Hezbollah did not use civilians as human shields. Israeli Ambassador to the United States, Dan Gillerman, said early in the war: "To those countries who claim that we are using disproportionate force, I have only this to say - you are damn right we are."

Mearsheimer discussed American public opinion of this unconditional support, saying that Americans are more critical of Israel and in tune with Europeans than their government, as a majority want to be neutral. The Israeli lobby was key in this war, a major driving force behind the United States' Middle East policy, and a setback to American and Israeli interests. Until the lobby favors a different approach, concluded Mearsheimer, or until its influence is weakened, American policy in the region will continue to face a serious dilemma.

Asked "How can elected officials support a balanced Middle-East policy when they do not gain benefits on principal?," Walt answered that the lobby is powerful and well-funded (a $\$ 50$ million annual budget) and advised an open discussion on the United States' national interest. Questioned about AIPAC's control of foreign policy, Walt replied that AIPAC had gained more influence after the Six Day war and in the 1980s and by selling the strategic ally argument.

To one participant who criticized Deputy Secretary of Defense Paul Wolfowitz and the Defense Department's former undersecretary for policy, Douglas Feith, Walt replied that Wolfowitz had persisted in pushing for an Iraqi invasion prior to $9 / 11$. Mearsheimer mentioned that the Israeli forces should have been far more selective and limited, as massive military force was counterproductive and did not make strategic sense. The final question was how Americans, including Muslims and others, can take back their foreign policy and make it more balanced. Walt answered that the costs of a failed foreign policy will ultimately occur and reality will set in. He advised Americans to continue to demand more from elected representatives, be informed, and encourage open debates to make the policy more consistent with our broader national interest.

The panel was covered live by $\mathrm{CNN}$ and was one of the most viewed programs.

Soha Srour

AJISS Assistant Editor

Herndon, Virginia 